\title{
Democracy and sustainable development
}

\author{
Dr.Anjali Mangesh \\ Associate Professor and H.O.D,Political Science Hislop College,Nagpur
}

\begin{abstract}
Democratic development in India lacks the social dimension of development, where the politicians tend to prioritize economic growth over societal growth. The case in the point is the Sardar Sarover Project (a series of dams) on the river Narmada, where there has been serious violation of the democratic, constitutional and human rights of the displaced people. They had to bear the cost of development and to sacrifice their rights over their resources, while they got no share in the benefits. The benefits of the entire project were accrued by the already privileged section of the society. This paper is a reflection on the importance of bringing back the social dimension in the development agenda; without which democracy will be meaningless.
\end{abstract}

Democracy is the dominant organizing political system of the early twenty-first century. It is the bestalthough far from perfect- political system so far devised to enable people to make well-informed and accountable decisions, and to arrive at accommodations among competing values and ideas. ${ }^{1}$ We cherish democracy in India: the rule of the people, by the people, and for the people. But democracy is undermined by decision-making that is democratic in name only. It is threatened by conflict, apathy, inequality, manipulation and corruption. ${ }^{2}$ It is failing to deliver egalitarian and sustainable model of democratic development.

The development projects like Narmada dams were initiated in post independent India for increased food production, electricity, irrigation, industrial production as well as drinking water to the people. However, the dams on river Narmada has displaced lakhs of people, without being adequately rehabilitated or getting any benefit from the project. This has resulted in the sufferings of large number of people and in violation of not only democratic rights but human rights also.

In the post-independent India, in the name of national interest or public purpose the state has acquired the land of the citizens. The argument of 'eminent domain' has been used in expropriation of the tribal population from their land. In the name of public purpose the state has asked a section of its citizens to sacrifice their rights so that the nation as a whole may benefit. This argument of public purpose allows the state to formulate development policy and setting of developing priorities of the people without people's participation. The argument of public purpose which allows the state to take away the land of the people without their consent is undemocratic and violates the democratic and constitutional rights of the displaced. ${ }^{3}$. The tendency of politicians in liberal democracies is to prioritize economic growth over those societal goals. In the entire Narmada dam project, the democratic principles of equality and social justice have been severely violated .The entire Narmada Valley Development plan has not contributed to the development of the people of Narmada Valley. People who have lost their land and their source of livelihood are not the same people who will benefit from increased electrification and irrigation. This is gross violation of their democratic rights to equality and Justice ${ }^{4}$.

It can be hard to imagine democracy without the promise of endless improvements in living standards, or even to imagine a form of democracy that has quality of life and sustainable development as its goals.However, the families displaced by Indira Sagar Pariyojana dam in Madhya Pradesh have shown lower standard of living,fallen by more than half as compared to pre-displacement years. ${ }^{5}$ The tribals of Jalsindhi, Domkhedi,Badal (M.P) affected by Sardar Sarover Project depended on land for their livelihood and common property resources such as grazing cattles and livestock. Agricultural land was fertile with abundant water and common property resources such as grazing land for cattles and livestock. The entire village was drowned and submerged in Sardar Sarover backwaters and they were left with no source of livelihood. ${ }^{6}$.In the absence of forests ,river and cultivable land all the sources of livelihood have been snatched away, reducing their selfsufficiency and independence. People such as artisans, business persons, boatmen and fisher folk were totally ignored in the rehabilitation process, leaving them with no compensation or alternative loss of their livelihoods. The tribes of Jalsindhi, Alirajpur and Anjanware depended on honey cultivation, poultry and fishing for their livelihood and nutritional ${ }^{7}$ Resettlement sites lack forests, grazing land or access to river and there is no provision for alternate source of livelihood, which is gross violation of their right to life under Art.21 of the constitution. Not providing agricultural land or grazing and alternatives to their traditional livelihood sources at the rehabilitation sites is a violation of their right to life. Employment opportunities in the Resettlement and Rehabilitation sites are nil; there are no opportunities to upgrade skills for unemployment; their means of livelihood have been submerged in the waters of Narmada and there are no means to rebuild their lives. Though 
the Supreme Court has interpreted Article 21 of right to life as every citizen's right to life with dignity, the acquisition of their land has led to the impoverishment of the ousted for a lifetime.

In a democratic society, the interests of all people affected by public decisions need to be taken into account. 'Nothing about us without us' should be the guiding principle and decision-makers at all levels should also be accountable to all affected people. ${ }^{8}$ In the case of Narmada dam, the democratic procedures and institutions were undermined and their was abysmal lack of information among the Sardar Sarover oustees about their displacement and dislocation. There was excessive central control in the process of planning and decision making.. In the villages of Kukshi and Alirajpur tehsils, no land acquisition notices were issued. The villagers were not informed about which areas would come under submergence or when they would be required to leave; or the rate of compensation and the like. ${ }^{9}$ The people who were to be displaced by the dams on river were never consulted during any stage of planning. At no stage was an attempt made to talk and understand the problems of the Project Affected Families or to enter into democratic negotiations with them. In spite of Panchayati Raj institutions in place, as a result of $73^{\text {rd }}$ amendment act, the local institutions were sidelined. The Panchayat Extension to scheduled Areas or PESA act of 1996 requires gram sabhas to be consulted for land acquisition. ${ }^{10}$ In a democratic system of governance, all the citizens have a right to be heard. They can put forward their agreements and disagreements which constitute an important feature of democracy. ${ }^{11}$ When the people raised their voice against the violation of their rights, force was used against them. ${ }^{12}$ Democratic engagement through public participation, as well as access to information and access to justice, are among the core principles of democratic and sustainable development. ${ }^{13}$ At a highly aggregated level, violation of rights results in stress or tensions in the relationship between liberal democracy and sustainable development.

To conclude, democracy essentially requires adherence to rule of law. In perspective, the rule of law, defended by an independent judiciary, plays a crucial function by ensuring that civil and political rights and civil liberties are safe and the equality and dignity of all citizens are not at risk. It also helps to protect the needs of the greatest number of citizens to strengthen the dimensions of rights, equality, and accountability. ${ }^{14}$ Short-term electoral gains too often dictate political priorities in mega development projects like Sardar Sarover project. Yet, long-term thinking is precisely what is required to ensure that actions are taken now to forestall the risk of possible failure of democracy in the future.

If democracy is to survive and thrive, it will likely have to outperform the social and democratic challenges. We need to understand the challenges faced by democracy while dealing with development. First, there is a need for long-term thinking to ensure that actions are taken now to prevent the risk of damaging the democratic fabric. Second, politicians tend to prioritize economic growth over societal goal. The greatest challenge lies in bringing back the social dimension in the development agenda.

A people-cantered, participatory, socially transformative and sustainable and inclusive route to development while retaining and nurturing an active commitment to vibrant democracy is the third challenge. Initiatives at all levels to strengthen democratic decision-making and participation by, and representation of all the people affected by public decisions need to be taken in order to strengthen democracy. ${ }^{15}$ The development policy we have followed after Independence has resulted in the exclusion and marginalization of the underprivileged specially the tribal groups in terms of claims over resources. ${ }^{16}$ The meaning of development was interpreted only in terms of economic growth and did not take into account the violation of cultural, social and equity rights of the people. ${ }^{17}$. The social costs have been altogether ignored making this project the world's largest planned human tragedy. ${ }^{18}$ The development project which was meant to be for the welfare of the people has resulted in violating the rights of those whose rights it intended to protect. We need to understand mutual interdependence and vital linkage between democracy and development. Without democratization, development will not be sustainable. At the same time, without progress in human development and economic growth, democratization will rest on very fragile foundations. The path towards simultaneous sustainable development and democratization is therefore "to collapse both processes into one by making development itself a process of democratization". .9

\section{References}

[1]. Ward Halina, part of a series of think pieces in' Equipping Democracy to Deliver Sustainable Development ; link,http.//www.unrisd.org

[2]. Ward Halina, part of a series of think pieces in' Democracy and Sustainable Development 'link, http.//www.unrisd.org

[3]. Jayal Gopal Nirija, 'The democratic State', Oxford University Press, 2002, Pg, 231

[4]. Patkar Medha,Displacement and displaced ;Role in Project Planning,' South Asia Network on Dams,Rivers and People,New Delhi,October 2000

[5]. Desai Kaivalya,Jain Vineet Panday Rahul,P.Srikant,Trivedi Upmanyu,'Rehabilitation of the Indira Sagar Pariyojana Displaced,'EPW,Dec 22,2007.

[6]. Thakker Himanshu,'Restoring Sanity in water use,'Seminar 541,September 2004,Pg.39

[7]. On my personal visit to Narmada Valley and to Alirajpur, Jalsindhi and Badal villages on August,2009.

[8]. Lloyd M. Sachikonye. Democracy, Sustainable Development and Poverty; Are They Compatible? Pg.15

[9]. As in the transcript of the letter dictated in Bhilala by Bava Mahalia of Jalsindhi village Alirajpurs,District Jhabua addressed to the Chief Minister of Madhya Pradesh,published by INTACH,Kerala,1994,Pg.39 
[10]. Sanghvai Sanjay, "River and life", Earthcare Books, 2000, Pg.29.

[11]. . .Tandon Rajesh, "Grassroots democracy", Seminar 451, March 1997, Pg. 37.

[12]. Baviskar Amita,'Who speaks for the victims', Seminar 451,March 1997,Pg 59

[13]. Linkages between the rule of law, democracy and sustainable development, Thursday, 19 April, from 13.15 to 14.45 at the Permanent Mission of Italy to the UN ， 885

[14]. Statement by the President of the Security Council, S/PRST/2012/1, 19 January 2012. "Delivering justice: program me of action to strengthen the rule of law at the international levels", A/66/749, 16 March 2012

[15]. Lloyd M. Sachikonye. Democracy, Sustainable Development and Poverty; Are They Compatible? Pg. 15

[16]. Palsikar Suhas,'Of Democracy and Diversity,',Seminar 81,January 2008

[17]. Sach Wolfgang,'The idea of Development,'Wolfgang Publications, 1998

[18]. Alveres Claude and Billorey Ramesh, 'Damming the Narmada,' Third World Network and Asia-Pacific People's environmental Network,1988,Pg.14

[19]. (Ake 2000) Lloyd M. Sachikonye. Democracy, Sustainable Development and Poverty; Are They Compatible? Pg.15 